\title{
Chemical Composition and Evaluation of Antibacterial and Antioxidant Activities of the Essential oil of Croton urucurana Baillon (Euphorbiaceae) Stem Bark
}

\author{
Euclésio Simionatto, ${ }^{*, a}$ Vanderléa F. L. Bonani, ${ }^{a}$ Ademir Farias Morel, ${ }^{c}$ Nilva Ré Poppi, ${ }^{b}$ \\ Jorge Luiz Raposo Júnior, ${ }^{b}$ Caroline Z. Stuker, ${ }^{c}$ Gisele M. Peruzzo, ${ }^{a}$ Marize T. L. P. Peres ${ }^{a}$ \\ and Sônia C. Hess ${ }^{a}$ \\ ${ }^{a}$ Departamento de Hidráulica e Transportes, Universidade Federal de Mato Grosso do Sul, \\ 79070-900 Campo Grande-MS, Brazil \\ ${ }^{b}$ Departamento de Química, Universidade Federal de Mato Grosso de Sul, \\ 79070-900 Campo Grande-MS, Brazil \\ ${ }^{c}$ Departamento de Química, Universidade Federal de Santa Maria, \\ 97105-900 Santa Maria-RS, Brazil
}

\begin{abstract}
O óleo essencial obtido a partir das cascas do caule de Croton urucurana Baillon (Euphorbiaceae) foi analisado por CG e CG-EM. 83 compostos foram identificados, sendo borneol $(14,7 \%)$, acetato de bornila (5,2\%), 1-isopropil-7-metil-4-metileno-1,3,4,5,6,8-hexaidro$2 \mathrm{H}$-naftalen-4a-ol (14,7\%), sesquicineol $(10,5 \%)$ e epóxido de $\gamma$-gurjuneno $(5,4 \%)$ os principais componentes. Para o óleo essencial bruto, foi determinada em $3,21 \mathrm{mg} \mathrm{mL}^{-1}$ a $\mathrm{EC}_{50}$ no ensaio de atividade antioxidante frente ao radical livre DPPH. A fração do óleo essencial bruto que apresentou atividade antioxidante foi purificada por CCD sobre sílica gel. Análises de CG e CG-EM revelaram que $\alpha$-bisabolol $(38,3 \%), \alpha$-eudesmol $(9,3 \%)$ e guaiol $(8,2 \%)$ são os principais componentes da fração antioxidante. $\mathrm{A} \mathrm{EC}_{50}$ medida no teste frente ao DPPH foi de $1,05 \mathrm{mg}$ $\mathrm{mL}^{-1}$ para a fração bioativa. Foi determinada a atividade antimicrobiana do óleo essencial bruto frente a sete bactérias Gram-positivas e Gram-negativas e três fungos. Os valores de CIM medidos variaram de 1,25 a $10,00 \mathrm{mg} \mathrm{mL}^{-1}$.
\end{abstract}

The essential oil obtained from the stem bark of Croton urucurana Baillon (Euphorbiaceae) was analysed by GC and GC-MS. 83 compounds were identified and borneol (14.7\%), bornyl acetate $(5.2 \%)$, 1-isopropyl-7-methyl-4-methylene-1,3,4,5,6,8-hexahydro-2H-naphthalen-4a-ol (14.7\%), sesquicineole (10.5\%) and $\gamma$-gurjunene epoxide (5.4\%) were the main components. The $\mathrm{EC}_{50}$ value of the crude essential oil in the DPPH free radical scavenging assay was $3.21 \mathrm{mg} \mathrm{mL}^{-1}$. The fraction of the crude essential oil that presented antioxidant activity was purified by prepTLC on silica gel. GC and GC-MS analysis revealed that $\alpha$-bisabolol $(38.3 \%), \alpha$-eudesmol $(9.3 \%)$ and guaiol (8.2\%) were the main components of the antioxidant fraction. The $\mathrm{EC}_{50}$ value measured for the bioactive oil fraction in the DPPH assay was $1.05 \mathrm{mg} \mathrm{mL}^{-1}$. The antimicrobial activity of the crude essential oil was assayed against seven Gram-positive and Gram-negative bacteria and three yeasts. Measured MIC values ranged from 1.25 to $10.00 \mathrm{mg} \mathrm{mL}^{-1}$.

Keywords: Croton urucurana, essential oil, antioxidant, DPPH assay, antimicrobial acticity

\section{Introduction}

Croton (Euphorbiaceae) is one of the largest genera of flowering plants, with nearly 1,300 species of herbs, shrubs, and trees that are ecologically prominent and often important elements of secondary vegetation in the tropics and subtropics worldwide. ${ }^{1}$ Extracts (or infusions) of the

*e-mail: eusimionatto@yahoo.com.br different parts of the plant of several species of the genus Croton as C. lechleri, C. palanostigma, C. draconoides and $C$. urucurana are traditional remedies well known for their healing powers and are extensively used by indigenous cultures of the Amazon River for the treatment of infected wounds and to hasten wound healing. ${ }^{2-8}$ Its stem bark, when slashed, releases a blood-red sap and, for this reason, $C$. urucurana and other species of the genus Croton are known as Dragon's Blood (or Sangra d'água in Brazil). 
Previous works reported that the essential oils from northeastern Brazilian Croton species, C. zenhtneri, $C$. nepetaefolius and $C$. argyrophylloides, exhibited good antioxidant activities. ${ }^{9}$ Croton urucurana Baillon (Euphorbiaceae) is a tree commonly found in Paraguay, northern Argentina, southern Brazil, and Uruguay. Three different products from this species are used primarily in folk medicine: the red sap, the stem bark, and the gum exudate. ${ }^{10}$

Many pharmacological effects of Croton urucurana have been described in literature, which include wound and ulcer healing, antidiarrhoeic, anticancer, intestinal anti-inflammatory, antioxidant and antirheumatic properties. ${ }^{11-14,28}$ Peres et al. ${ }^{15}$ reported the antibacterial activity against Staphylococcus aureus and Salmonella typhimurium of the aqueous-EtOH extract, some fractions of the methanolic extract, catechin and acetyl aleuritolic acid obtained from C. urucurana.

Previous phytochemical analysis of Croton urucurana have identified the presence of acetyl aleuritolic acid, catechin, gallocatechin, sonderianin, $\beta$-sitosterol and its glucoside, stigmasterol, campesterol and two novel clerodane diterpenes. ${ }^{13,15,16}$ Fucoarabinogalactan, a polysaccharide, has been isolated from the gum exudate of $C$. urucurana. ${ }^{17}$ In this study, we report the chemical composition, antioxidant ${ }^{29}$ and antimicrobial activities of the essential oil obtained from the stem bark of Croton urucurana.

\section{Experimental}

\section{Plant Material}

The stem bark of Croton urucurana was collected in February and March 2006, from biological reserve of Federal University of Mato Grosso do Sul, at the town of Campo Grande, Mato Grosso do Sul state, Brazil. Voucher specimens (16859) have been deposited at the Herbarium of Federal University of Mato Grosso do Sul.

\section{Essential oil isolation}

The stem bark was subjected to hydrodistillation for 4 $\mathrm{h}$ using a modified Clevenger-type apparatus, followed by exhaustive extraction of the distillate with hexane. After removal of the solvent, the yield of the crude oil was $0.05 \%$. The physical properties for oil were: $[\alpha]_{D}^{25}: 0.91$; $[\alpha]_{\mathrm{D}}^{25}: 1.56 ;[\alpha]_{\mathrm{D}}^{25}:-12.1\left(\right.$ in $\left.\mathrm{CHCl}_{3}, c=0.025\right)$.

\section{Gas Chromatography/Mass Spectrometry analysis}

Analysis of the oil was performed using a Varian GCMS-MS system comprising a CP-3900 gas chromatograph
(Walnut Creek, CA, USA) with a 1077 injector, a CP8410 autosampler and an ion-trap mass spectrometer (Varian Saturn 2100). Separations were carried out using a ZB-5 (5\%-phenyl-95\%-dimethylpolysiloxane) fusedsilica capillary column $(30 \mathrm{~m} \times 0.25 \mathrm{~mm}$ i.d., $0.25 \mu \mathrm{m}$ film thickness) from Phenomenex (Torrance, CA, USA). Oven temperature was programmed from 50 to $250{ }^{\circ} \mathrm{C}$ at $3{ }^{\circ} \mathrm{C} \mathrm{min}{ }^{-1}$. The temperatures of the manifold, GC-MS interface and the ion trap were 70,240 and $200{ }^{\circ} \mathrm{C}$, respectively. Helium $(99.999 \%)$ was used as carrier gas at a constant flow of $1.0 \mathrm{~mL} \mathrm{~min}^{-1}$ and an injection volume of $1 \mu \mathrm{L}$ was employed (split ratio of 1:20). The MS scan parameters included electron impact ionization voltage of $70 \mathrm{eV}$, a mass range of $41-380 \mathrm{~m} / \mathrm{z}$ and a scan interval of $0.5 \mathrm{~s}$.

A $\mathrm{C}_{9}-\mathrm{C}_{21} n$-alkanes mixture diluted in n-hexane was prepared for determination of the temperature programmed retention indices. Samples diluted in $n$-hexane were analyzed. Internal standards ( $n$-alkanes) were then added to each sample to aid in the standardization of retention times and the samples were analyzed again. Retention indices (RI) for all compounds were determined according to the Van den Dool and Kratz. ${ }^{27}$

\section{Identification of essential oil constituents}

The identification of the components was based on comparison of their mass spectra with those of NIST 2.0 and Saturn Libraries and those described by Adams, ${ }^{18}$ as well as by comparison of their retention indices with literature data. ${ }^{18}$

\section{DPPH assay on TLC}

Hydrogen atom- or electron-donation ability of the corresponding oils was measured from the bleaching of the purple-colored methanol solution of 2,2diphenylpicrylhydrazyl (DPPH). Five microliters of a 1:10 dilution of the oils in hexane were applied to the TLC plates (aluminum sheets covered with silica gel $60 \mathrm{~F}_{254}$, Merck) and hexane-ethyl acetate (9:1) mixture was used as eluent. The plate was sprayed with a $0.2 \% \mathrm{DPPH}$ reagent in methanol and left at room temperature for 30 min. Yellow spots formed from bleaching of the purple colour of DPPH reagent were evaluated as positive antioxidant activity. ${ }^{19}$

\section{Spectrophotometric DPPH assay}

This spectrophotometric assay uses stable DPPH radical as a reagent. ${ }^{20,21}$ Fifty microliters of various concentrations of the oils in methanol were added to $5 \mathrm{~mL}$ of a $0.004 \%$ 
methanol solution of DPPH. After a 30 min incubation period at room temperature, the absorbance was read against a blank at $517 \mathrm{~nm}$. Inhibition of DPPH free radical in percent (I\%) was calculated in following way:

$$
\mathrm{I} \%=\left(\mathrm{A}_{\text {blank }}-\mathrm{A}_{\text {sample }}\right) \times 100
$$

where $\mathrm{A}_{\text {blank }}$ is the absorbance of the control reaction (containing all reagents except the test compound), and $\mathrm{A}_{\text {sample }}$ is the absorbance of the test sample. Oil concentration providing $50 \%$ inhibition $\left(\mathrm{IC}_{50}\right)$ was calculated from the graph plotting inhibition percentage against oil concentration. Tests were carried out in triplicate. Commercial standard antioxidant butylated hydroxytoluene (BHT) was also tested against DPPH and used as a reference.

\section{Isolation of antioxidant fraction}

For the isolation of the antioxidant compounds, 100 mg of the crude oil were submitted to preparative TLC (silicagel $60 \mathrm{GF}_{254}$, Merck; hexane-EtOAc, 90:10). The antioxidant fraction was detected by application of the DPPH solution $(0.2 \%$ in ethanol) on the lateral of the plate. This fraction was withdrawn and washed with EtOAc to give the antioxidant fraction $(6 \mathrm{mg})$.

Isolation of 1-isopropyl-7-methyl-4-methylene-1,3,4,5,6,8hexahydro-2H-naphthalen-4a-ol (1)

$100 \mathrm{mg}$ of crude essential oil of C. urucurana was further submitted to preparative TLC ( $\mathrm{SiO} 2$; hexane-EtOAc, 85:15) afforded 1 (12 mg). Detection was achieved by UV light $(254 \mathrm{~nm})$ and by spraying with solutions of $10 \% \mathrm{H}_{2} \mathrm{SO}_{4}$ and $2 \%$ vanillin in ethanol/ $\mathrm{H}_{2} \mathrm{SO}_{4}$, followed by heating. The structure of (1) was deduced chiefly from GC-MS analyses and ${ }^{1} \mathrm{H} /{ }^{13} \mathrm{C}$ NMR experiments. The relative configuration was additionally confirmed by comparison of the spectral data and retention indices of isomers with those from leterature. ${ }^{25}(\mathbf{1})$ : $[\alpha]_{\mathrm{D}}^{25}:+4.9$ ( in $\left.\mathrm{CHCl}_{3}, c=0.0075\right)$; ${ }^{1} \mathrm{H}$ NMR (300 MHz, $\left.\mathrm{CDCl}_{3}\right): \delta 5.52$ (brs, $\left.1 \mathrm{H}\right), 4.73(\mathrm{~s}, 1 \mathrm{H}), 4.68(\mathrm{~s}, 1 \mathrm{H}), 2.47-2.51$ (m, 2H), 2.22-2.26 (m, 2H), 2.01-2.04 (m, 2H), 1.80-1.85 (m, 2H), 1.71-1.74 (m, 1H), $1.67(\mathrm{~m}, 1 \mathrm{H}), 1.59(\mathrm{~m}, 1 \mathrm{H}), 1.22(\mathrm{~s}$, $3 \mathrm{H}), 0.98$ (d, J $2.7 \mathrm{~Hz}, 3 \mathrm{H}), 0.95$ (d, $J 2.7 \mathrm{~Hz}, 3 \mathrm{H}) ;{ }^{13} \mathrm{C} \mathrm{NMR}$ $\left(75 \mathrm{MHz}, \mathrm{CDCl}_{3}\right) \delta$ 21.2, 21,4, 24.0, 24.7, 30.0, 37.0, 37.4, 40.2, 45.0, 55.0, 80.6, 106.4, 121.3, 149.7, 153.9; EI-MS: $m / z=220[\mathrm{M}]^{+}, 202,187,159,134,119,91$.

\section{Antimicrobial activity}

The antibacterial activity of the crude oil was assayed using the broth micro dilution method. A collection of ten microorganisms were used, including four Gram-positive bacteria: Staphylococcus aureus (ATCC 6538p), Staphylococcus epidermidis (ATCC 12228), Pseudomonas aeruginosa (ATCC27853) and Bacillus subtilis (ATCC 6633), three Gram-negative bacteria: Klebsiella pneumoniae (ATCC 10031), Escherichia coli (ATCC 11103) and Salmonella setubal (ATCC 19796), and three yeasts: Saccharomyces cerevisiae (ATCC 2601), Cryptococcus neoformans (ATCC 28952) and Candida albicans (ATCC 10231). Standard strains of microorganisms were obtained from American Type Culture Collection (ATCC), and standard antibiotics chloramphenicol and nistatine were used in order to control the sensitivity of the microbial test. ${ }^{22}$ The minimal inhibitory concentration (MIC) was determined on 96 well culture plates by a micro dilution method using a microorganism suspension at a density of $10^{5} \mathrm{CFU} \mathrm{mL} \mathrm{mL}^{-1}$ with Casein Soy Broth incubated for $24 \mathrm{~h}$ at $37^{\circ} \mathrm{C}$ for bacteria, and Sabouraud Broth incubated for 72 $\mathrm{h}$ at $25^{\circ} \mathrm{C}$ for yeasts. The cultures that did not present growth were used to inoculate plates of solid medium (Muller Hinton Agar and Sabouraud Agar) in order to determine the minimal letal concentration (MLC). Proper blanks were assayed simultaneously and samples were tested in triplicate. Technical data have been described previously. ${ }^{23,24}$

\section{Results and Discussion}

In every extractions were used $100 \mathrm{~g}$ of Croton urucurana stem bark and the crude oil yield was $0.05 \%$. The GC-MS analysis led to the identification and quantification of a total of 83 components (Table 1), accounting for $94.6 \%$ of the total components present in the crude essential oil of $C$. urucurana.

As shown in Table 1, borneol (14.7\%), bornyl acetate $(5.2 \%)$, o-cymene $(3.2 \%)$, terpineol $(2.8 \%)$ and 1,8 cineole $(1.8 \%)$ were the main monoterpenes identified in the $C$. urucurana stem bark essential oil. The analysis also showed that the essential oil is constituted by a high proportion of sesquiterpenes, dominated by sesquicineole (10.5\%), 1-isopropyl-7-methyl-4-methylene-1,3,4,5,6,8hexahydro-2H-naphthalen-4a-ol $(14.7 \%), \gamma$-gurjunene epoxide (5.4\%), $\alpha$-bisabolol (1.8\%), elemenone (1.8\%) and $\alpha$-eudesmol $(1.5 \%)$.

The crude essential oil of C. urucurana stem bark (100 $\mathrm{mg}$ ) was subjected to repeated preparative thin layer chromatography on silicagel to afford the derivative of cadinane-type sesquiterpene 1-isopropyl-7-methyl-4methylene-1,3,4,5,6,8-hexahydro-2H-naphthalen-4a-ol (1, 12 $\mathrm{mg}$ ), that is the main sesquiterpene component of the essential oil. Compound $\mathbf{1}$ was obtained as an colorless oil and its structure was established on the basis of the ${ }^{1} \mathrm{H}$ and ${ }^{13} \mathrm{C}$ 
Table 1. Percentage composition of the stem bark essential oil from Croton urucurana Bailon and of the antioxidant fraction

\begin{tabular}{|c|c|c|c|c|c|}
\hline & Compounds ${ }^{\mathrm{a}, \mathrm{b}}$ & Crude essential oil & Antioxidant fraction & $\mathrm{RI}^{\mathrm{c}}$ & Mass spectral data ${ }^{\mathrm{d}}$ \\
\hline 01 & tricyclene & 0.1 & - & 926 & $136[\mathrm{M}]^{+}, \quad 93$ \\
\hline 02 & $\alpha$-thujene & 0.1 & - & 931 & $136[\mathrm{M}]^{+}, \quad 91$ \\
\hline 03 & $\alpha$-fenchene & 0.6 & - & 951 & $136[\mathrm{M}]^{+}, \quad 93$ \\
\hline 04 & sabinene & 0.1 & - & 976 & $136[\mathrm{M}]^{+}, 93$ \\
\hline 05 & myrcene & 0.2 & - & 991 & $136[\mathrm{M}]^{+}, \quad 41$ \\
\hline 06 & $\alpha$-terpinene & 0.1 & - & 1018 & $136[\mathrm{M}]^{+}, 121$ \\
\hline 07 & $o$-cymene & 3.2 & - & 1022 & $134[\mathrm{M}]^{+}, 119$ \\
\hline 08 & limonene & 0.2 & - & 1031 & $136[\mathrm{M}]^{+}, \quad 67$ \\
\hline 09 & 1,8-cineole & 1.8 & - & 1033 & $154[\mathrm{M}]^{+}, 43$ \\
\hline 10 & $\gamma$-terpinene & 0.3 & - & 1062 & $136[\mathrm{M}]^{+}, \quad 93$ \\
\hline 11 & terpinolene & 0.1 & - & 1087 & $136[\mathrm{M}]^{+}, \quad 93$ \\
\hline 12 & linalool & 0.3 & - & 1099 & $154[\mathrm{M}]^{+}, 43$ \\
\hline 13 & trans-thujone & 0.1 & - & 1115 & $152[\mathrm{M}]^{+}, \quad 67$ \\
\hline 14 & menth-2-en-1-ol & 0.1 & - & 1120 & $154[\mathrm{M}]^{+}, \quad 43$ \\
\hline 15 & camphor & 0.5 & - & 1142 & $152[\mathrm{M}]^{+}, \quad 95$ \\
\hline 16 & camphene hydrate & 0.4 & - & 1146 & $154[\mathrm{M}]^{+}, 43$ \\
\hline 17 & tagetone & 0.1 & - & 1152 & $152[\mathrm{M}]^{+}, \quad 67$ \\
\hline 18 & isoborneol & 0.2 & - & 1155 & $154[\mathrm{M}]^{+}, \quad 95$ \\
\hline 19 & cis-chrysanthenol & 0.2 & - & 1161 & $152[\mathrm{M}]^{+}, \quad 81$ \\
\hline 20 & borneol & 14.7 & 0.4 & 1164 & $154[\mathrm{M}]^{+}, \quad 95$ \\
\hline 21 & terpinen -4-ol & 2.8 & 2.5 & 1175 & $154[\mathrm{M}]^{+}, \quad 71$ \\
\hline 22 & $p$-cymen-8-ol & 0.1 & 1.0 & 1183 & $150[\mathrm{M}]^{+}, \quad 43$ \\
\hline 23 & $\alpha$-terpineol & 1.2 & - & 1189 & $154[\mathrm{M}]^{+}, \quad 59$ \\
\hline 24 & myrtenol & 0.1 & - & 1195 & $152[\mathrm{M}]^{+}, \quad 79$ \\
\hline 25 & isobornyl formate & 0.4 & - & 1227 & $182[\mathrm{M}]^{+}, \quad 95$ \\
\hline 26 & thymol methyl ether & 0.2 & - & 1230 & $164[\mathrm{M}]^{+}, 149$ \\
\hline 27 & $E$-ocimenone & 0.1 & - & 1234 & $150[\mathrm{M}]^{+}, 135$ \\
\hline 28 & bornyl acetate & 5.9 & - & 1285 & $196[\mathrm{M}]^{+}, \quad 43$ \\
\hline 29 & thymol & 0.2 & 2.7 & 1291 & $150[\mathrm{M}]^{+}, 135$ \\
\hline 30 & carvacrol & 0.1 & 0.8 & 1300 & $150[\mathrm{M}]^{+}, 135$ \\
\hline 31 & $\delta$-elemene & 0.6 & - & 1337 & $204[\mathrm{M}]^{+}, 121$ \\
\hline 32 & cyclosativene & 0.2 & - & 1367 & $204[\mathrm{M}]^{+}, 105$ \\
\hline 33 & $\alpha$-copaene & 0.1 & - & 1375 & $204[\mathrm{M}]^{+}, 105$ \\
\hline 34 & $\beta$-elemene & 0.3 & - & 1392 & $204[\mathrm{M}]^{+}, \quad 67$ \\
\hline 35 & cyperene & 0.3 & - & 1399 & $204[\mathrm{M}]^{+}$ \\
\hline 36 & $\alpha$-cedrene & 0.2 & - & 1408 & $204[\mathrm{M}]^{+}, 119$ \\
\hline 37 & $\delta$-gurjunene & 0.3 & - & 1413 & $204[\mathrm{M}]^{+}, 105$ \\
\hline 38 & $\beta$-cedrene & 1.3 & - & 1420 & $204[\mathrm{M}]^{+}, 161$ \\
\hline 39 & cis-thujopsene & 2.4 & - & 1424 & $204[\mathrm{M}]^{+}, 119$ \\
\hline 40 & $\gamma$-elemene & 0.5 & - & 1430 & $204[\mathrm{M}]^{+}, 121$ \\
\hline 41 & geranyl acetone & 0.4 & - & 1452 & $194[\mathrm{M}]^{+}, 43$ \\
\hline 42 & 9-epi-caryophyllene & 0.2 & - & 1465 & $204[\mathrm{M}]^{+}, \quad 41$ \\
\hline 43 & $\gamma$-gurjunene & 0.5 & - & 1470 & $204[\mathrm{M}]^{+}, 105$ \\
\hline 44 & $\gamma$-himachalene & 0.3 & - & 1474 & $204[\mathrm{M}]^{+}, 105$ \\
\hline 45 & g-muurolene & 0.4 & - & 1477 & $204[\mathrm{M}]^{+}, 161$ \\
\hline 46 & curcumene & 0.1 & - & 1483 & $204[\mathrm{M}]^{+}, 119$ \\
\hline 47 & $\beta$-selinene & 0.4 & - & 1486 & $204[\mathrm{M}]^{+}, \quad 93$ \\
\hline 48 & $\alpha$-selinene & 1.4 & - & 1493 & $204[\mathrm{M}]^{+}, \quad 93$ \\
\hline 49 & $\beta$-himalachene & 0.3 & - & 1500 & $204[\mathrm{M}]^{+}, 119$ \\
\hline 50 & cuparene & 0.4 & - & 1505 & $202[\mathrm{M}]^{+}, 132$ \\
\hline 51 & sesquicineole & 10.5 & - & 1514 & $222[\mathrm{M}]^{+}, 139$ \\
\hline 52 & $\delta$-cadinene & 0.8 & - & 1524 & $204[\mathrm{M}]^{+}, 119$ \\
\hline 53 & trans-calamenene & 1.8 & 0.1 & 1534 & $202[\mathrm{M}]^{+}, 159$ \\
\hline 54 & $\alpha$-calacorene & 0.1 & - & 1543 & $200[\mathrm{M}]^{+}, 157$ \\
\hline 55 & nerolidol & 0.4 & 2.4 & 1564 & $222[\mathrm{M}]^{+}, \quad 41$ \\
\hline 56 & caryophyllene alchool & 1.1 & 1.5 & 1573 & $222[\mathrm{M}]^{+}, 111$ \\
\hline 57 & spathulenol & 0.3 & - & 1577 & $220[\mathrm{M}]^{+}, \quad 43$ \\
\hline 58 & sesquisabinene hydrate & 0.3 & - & 1579 & $222[\mathrm{M}]^{+}, \quad 41$ \\
\hline 59 & caryophyllene oxide & 0.4 & - & 1583 & $220[\mathrm{M}]^{+}, \quad 41$ \\
\hline 60 & khusimone & 0.6 & - & 1592 & $204[\mathrm{M}]^{+}, 119$ \\
\hline 61 & elemenone & 1.8 & - & 1597 & $219[\mathrm{M}]^{+}, 107$ \\
\hline 62 & guaiol & 0.4 & 8.2 & 1603 & $222[\mathrm{M}]^{+}, 161$ \\
\hline
\end{tabular}


Table 1. cont.

\begin{tabular}{|c|c|c|c|c|c|}
\hline & Compounds ${ }^{\mathrm{a}, \mathrm{b}}$ & Crude essential oil & Antioxidant fraction & $\mathrm{RI}^{\mathrm{c}}$ & Mass spectral data \\
\hline 63 & humulane-1,6-dien-3-ol & 0.3 & - & 1606 & $222[\mathrm{M}]^{+}, 109$ \\
\hline 64 & himachalene oxide & 0.2 & - & 1609 & $220[\mathrm{M}]^{+}, \quad 95$ \\
\hline 65 & 1,10-di-epi-cubenol & 0.8 & 2.3 & 1612 & $222[\mathrm{M}]^{+}, 161$ \\
\hline 66 & 10-epi- $\gamma$-eudesmol & 0.5 & - & 1618 & $222[\mathrm{M}]^{+}, 161$ \\
\hline 67 & $\gamma$-eudesmol & 0.7 & - & 1625 & $222[\mathrm{M}]^{+}, 161$ \\
\hline 68 & $\begin{array}{l}\text { 1-isopropyl-7- } \\
\text { methyl-4-methylene- } \\
\text { 1,3,4,5,6,8-hexahydro-2H- } \\
\text { naphthalen-4-ol* }\end{array}$ & 14.7 & 5.8 & 1629 & $220[\mathrm{M}]^{+}, 119$ \\
\hline 69 & $\beta$-acorenol & & 0.4 & 1634 & $222[\mathrm{M}]^{+}, 119$ \\
\hline 70 & cubenol & 0.5 & 1.6 & 1642 & $222[\mathrm{M}]^{+}, 161$ \\
\hline 71 & vulgarone-B & 0.5 & 4.0 & 1647 & $218[\mathrm{M}]^{+}, \quad 41$ \\
\hline 72 & $\alpha$-eudesmol & 1.5 & 9.3 & 1652 & $222[\mathrm{M}]^{+}, \quad 59$ \\
\hline 73 & $\alpha$-bisabolol oxide $\mathrm{B}$ & - & 0.4 & 1655 & $238[\mathrm{M}]^{+}, \quad 43$ \\
\hline 74 & 7-epi- $\alpha$-eudesmol & - & 0.3 & 1659 & $222[\mathrm{M}]^{+}, 161$ \\
\hline 75 & $\beta$-bisabolol & - & 1.8 & 1670 & $222[\mathrm{M}]^{+}, \quad 41$ \\
\hline 76 & $\gamma$-gurjunene epoxide & 5.4 & 0.3 & 1673 & $220[\mathrm{M}]^{+}, 107$ \\
\hline 77 & khusinol & 1.4 & 2.4 & 1676 & $220[\mathrm{M}]^{+}, \quad 41$ \\
\hline 78 & $\alpha$-bisabolol & 1.8 & 38.3 & 1684 & $222[\mathrm{M}]^{+}, \quad 43$ \\
\hline 79 & epi- $\alpha$-bisabolol & - & 0.6 & 1685 & $222[\mathrm{M}]^{+}, \quad 43$ \\
\hline 80 & acorenone & 0.5 & - & 1689 & $220[\mathrm{M}]^{+}, \quad 41$ \\
\hline 81 & ni & 0.2 & - & 1707 & $220[\mathrm{M}]^{+}, 119$ \\
\hline 82 & 8-oxo-neoisolonlongifolene & 0.1 & - & 1808 & $218[\mathrm{M}]^{+}, 175$ \\
\hline \multirow[t]{2}{*}{83} & thunbergol & 0.1 & - & 1825 & $290[\mathrm{M}]^{+}, \quad 43$ \\
\hline & TOTAL & 94.6 & 87.1 & & \\
\hline
\end{tabular}

aCompounds listed in order of elution from a ZB-5 column; ' ${ }^{\mathrm{a}}$ Identification: RI, retention indeces, GC-MS, gas chromatography-mass spectroscopy; *Identified by RI, GC-MS and NMR (nuclear magnetic ressonance); ${ }^{\circ}$ Programmed temperature retention indices determined on apolar ZB-5 column (50$\left.250{ }^{\circ} \mathrm{C} ; 3{ }^{\circ} \mathrm{C} \mathrm{min}^{-1}\right) ;{ }^{\mathrm{d}}$ Molecular ion $[\mathrm{M}]^{+}$and major fragment abtained from GC-MS analyses.

NMR spectra. This is the first report on the occurrence of 1 in C. urucurana and in the Euphorbiaceae family, but this compound has previously been isolated from the essential oil of Aglaia odorata Lour (Meliaceae) flowers. ${ }^{25}$

Next, DPPH free radical scavenging activity of crude essential oil was investigated. The model system of scavenging DPPH free radicals is a simple method to evaluate antioxidant activity. It is accepted that the DPPH free radical scavenging by antioxidants is due to their hydrogen-donating ability. ${ }^{26}$ The essential oil of $C$. urucurana stem bark exhibited the $\mathrm{IC}_{50}$ of $3.21 \mathrm{mg} \mathrm{mL}^{-1}$ in the DPPH free radical scavenging activity spectrophotometric assay. $\mathrm{This} \mathrm{IC}_{50}$ value reveals that the tested essential oil is a weaker oxidant agent than the commercial standard antioxidant BHT, that presented $\mathrm{IC}_{50}$ $0.18 \mathrm{mg} \mathrm{mL}^{-1}$ in the same test system. The isolated sesquiterpene 1-isopropyl-7-methyl-4-methylene1,3,4,5,6,8-hexahydro-2H-naphthalen-4a-ol (1) showed no antioxidant activity.

Since the crude essential oil of $C$. urucurana stem bark exhibited antioxidant capacity in the DPPH test, it was submitted to prep-TLC, affording the fraction $(6.0 \mathrm{mg})$ that is responsible for the antioxidant activity in the oil. After isolation, this fraction was analyzed by GC-MS for determination of the components. The GC-MS analysis of the antioxidant fraction of the essential oil of $C$. urucurana led to the identification and quantification of a total of the 21 major components (Table 1) accounting for $87.1 \%$ of the total components present and the main compounds are $\alpha$-bisabolol (38.3\%), $\alpha$-eudesmol (9.3\%) and guaiol (8.2\%). These three compounds were present in the crude essential oil of $C$. urucurana stem bark in very lower yields.

The antioxidant fraction of the crude essential oil exhibited the $\mathrm{IC}_{50}$ of $1.05 \mathrm{mg} \mathrm{mL}^{-1}$ in the DPPH free radical scavenging assay. The measured $\mathrm{IC}_{50}$ indicates that this oil is also a weaker antioxidant agent than BHT.

The antimicrobial activity of the essential oils was examined by broth microdilution susceptibility assay against a panel of 10 microorganisms. The results, presented in Table 2, reveal that the crude essential oil of C. urucurana stem bark inhibited the growth of all microorganisms and that S. epidermidis and E. coli (MIC $=1.25 \mathrm{mg} \mathrm{mL}^{-1}$ ) were the most sensitive, while $B$. subtilis and $C$. albicans were the most resistant microorganisms (MIC $=10 \mathrm{mg} \mathrm{mL}^{-1}$ ).

In comparison to the others essential oils from Croton species, ${ }^{9}$ the oil of the $C$. urucurana was more complex in composition. The main compounds found in the essential oil from C. urucurana, such as borneol, bornyl 
Table 2. Antimicrobial activity of the essential oil of C. urucurana stem bark (minimal inhibitory concentration (MIC) and the minimal letal concentration (MLC) in $\mathrm{mg} \mathrm{mL}^{-1}$ )

\begin{tabular}{lccc}
\hline Microrganisms $^{\mathrm{a}}$ & \multicolumn{2}{c}{ Essential oil } & Standard $^{\mathrm{b}, \mathrm{c}}$ \\
\cline { 2 - 4 } & $\mathrm{MIC}^{\mathrm{b}}$ & $\mathrm{MLC}^{\mathrm{b}}$ & MIC $^{\mathrm{b}}$ \\
\hline Staphylococcus aureus & 2.5 & $>20$ & $3.12 \times 10^{-3}$ \\
Staphylococcus epidermidis & 1.25 & $>20$ & $3.12 \times 10^{-3}$ \\
Bacillus subtilis & 10 & $>20$ & $3.56 \times 10^{-3}$ \\
Pseudomonas aeruginosa & 2.5 & $>20$ & $3.12 \times 10^{-3}$ \\
Escherichia coli & 1.25 & $>20$ & $3.12 \times 10^{-3}$ \\
Salmonella setubal & 2.5 & $>20$ & $1.56 \times 10^{-3}$ \\
Klebsiella pneumoniae & 5 & 5 & $10.3 \times 10^{-3}$ \\
Saccharomyces cerevisiae & 5 & 10 & $10.3 \times 10^{-3}$ \\
Candida albicans & 10 & 5 & $5.15 \times 10^{-3}$ \\
Cryptococcus neoformans & 5 & 5 & \\
\hline
\end{tabular}

${ }^{\mathrm{a}}$ ATCC (American Type Culture Collection); ${ }^{\mathrm{b}}$ Mean of 3 replicates in $\mathrm{mg} \mathrm{mL}^{-1}$; ${ }^{\mathrm{c}}$ Standard antimicrobial agents: chloramphenicol against bacteria and nistatine against yeasts.

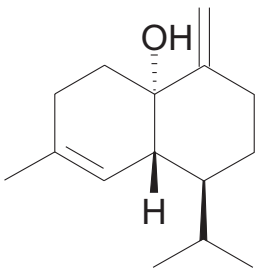

1

Figure 1. Structural formula of the derivative of cadinane-type sesquiterpene 1-isopropyl-7-methyl-4-methylene-1,3,4,5,6,8-hexahydro- $2 \mathrm{H}$ naphthalen-4-ol, main compound identified in the essential oil of stem bark from Croton urucurana.

acetate, sesquicineole, $\gamma$-gurjunene epoxide and the derivative of cadinane-type sesquiterpene (1) did not present in these others species.

\section{Supplemenatry Information}

Supplementary data are available free of charge at http://jbcs.sbq.org.br, as PDF file.

\section{Acknowledgments}

The authors are grateful to Fundação de Apoio ao Desenvolvimento de Ensino, Ciência e Tecnologia de Mato Grosso do Sul (FUNDECT/MS) and UFMS for the financial support. The authors also thank to $\mathrm{CNPq}$ for the IC, AT and DCR scholarships, to CAPES for the MS scholarship and Ubirazilda Resende for botanical support.

\section{References}

1. Webster, G. L.; Taxon 1993, 42, 793.

2. Chen, Z. P.; Cai, Y.; Phillipson, J D.; Planta Med. 1994, 60, 541.
3. Pieters, L.; De Bruyne, T.; Van Poel, B.; Vingerhoets Totte, J.; Vanden Berghe, D.; Vlietinck, A.; Phytomedicine 1995, $2,17$.

4. Esmeraldino, L.E.; Souza, A.M.; Sampaio, S.V.; Phytomedicine 2005, 12, 570 .

5. Gabriel, S. E.; Davenport, S. E.; Steagall, R. J.; Viaml, V.; Carlson, T.; Rozhon, R. J.; Am. J. Physiol. Gastrointest. Liver Physiol. 1999, 276, 58.

6. Holodniy, M.; Koch, J.; Mistal, M.; Schmidt, J. M.; Khandwala, A.; Pennington, J. E.; Porter, S. B.; Am. J. Gastroenterol. 1999, 94, 3267.

7. Miller, M.J.S.; MacNaughton, W. K.; Zhang, X. -J.; Thompson, J. H.; Charbonnet, R. M.; Bobrowski, P.; Lao, J.; Trentacosti, A.M.; Sandoval, M.; Am. J. Physiol. Gastrointest. Liver Physiol. 2000, 279, 192.

8. Jones, K.; J. Altern. Complement. Med. 2003, 9, 877.

9. Morais, S. M. de; Catunda Júnior, F. E. A.; da Silva, A. R. A.; Neto, J. S. M.; Rondina, D.; Cardoso, J. H. L.; Quim. Nova 2006, 29, 907.

10. Gonzalez Torres, D. M.; Catalogo de plantas Medicinales (Alimenticias y Utiles) Usadas en Paraguay. Asuncion, Paraguay, 1970.

11. Gurgel, L. A.; Sidrim, J. J. C.; Martins, D. T.; Filho, V. C;. Rao, V. S.; J. Ethnopharmacol. 2005, 97, 409.

12. Gurgel, L. A.; Silva, R. M.; Santos, F. A.; Martins, D. T.; Matos, P. O.; Rao, V. S.; Phytother. Res. 2001, 15, 319.

13. Peres, M. T. L. P.; Delle Monache, F.; Pizzolatti, M. G.; Santos, A. R. S.; Beirith, A.; Calixto, J. B.; Yunes, R. A.; Phytother. Res. 1998, 12, 209.

14. Orlandi-Mattos, P. E.; Geremias, R.; Cordova, C. A. S.; Creczynski-Pasa, T. B., Rebello, J. M.; Wilhem Filho, D.; Martins, D. T. O.; Llesuy, S.; Pedrosa, R. C.; Free Radical Biol. Med. 2002, 33, 645.

15. Peres, M.T.L.P.; Delle Monache, F.; Cruz, A.B.; Pizzolatti, M.G.; Yunes, R.A.; J. Ethnopharmacol. 1997, 56, 223.

16. Peres, M.T.L.P.; Pizzolatti, M.G.; Yunes, R.A.; Delle Monache, F.; Phytochemistry 1998, 49, 171. 
17. Milo, B.; Risco, E.; Vila, R., Iglesias, J.; Canigueral, S.; J. Nat. Prod. 2002, 65, 1143.

18. Adams, R. P.; Identification of Essential Oil Components by Gas Chromatography/Mass Spectroscopy, Allured Publishing: Illinois, 1995.

19. Mimica-Dukic, N.; Bozin, B.; Sokovic, M.; Mihajlovic, B.; Matavulj, B.; Planta Med. 2003, 69, 413.

20. Burits, M.; Bucar. F.; Phytother. Res. 2000, 14, 323.

21. Cuendet, M.; Hostettmann, K.; Potterat, O.; Helv. Chim. Acta 1997, 80, 1144.

22. FDA: Code of Federal Regulation 1991, 21, 300.

23. Hammer, K.A.; Carson, C.F.; Riley, T.V.; J. Appl. Microbiol. 1999, 86, 985 .
24. National Committee for Clinical Laboratory Standards: Reference Method of Broth Dilution Antifungal Susceptibility Testing of Yeasts. Standard M77-T, NCCLS: Villanova,1995.

25. Weyerstahl, P.; Marschall, H.; Son, P. T.; Giang, P. M.; Flav. Fragr. J. 1999, 14, 219.

26. Chen, C. W.; Ho, C. T.; J. Food Lip. 1995, 2, 35.

27. Van den Dool, H.; Kratz, P. D.; J. Chromatogr. 1963, 11, 463.

28. Salatino, A.; Salatino, M. L. F.; Negri, G.; J. Braz. Chem. Soc., 2007, 18, 11.

29. Núnez-Sélles, A. J.; J. Braz. Chem. Soc. 2005, 16, 699.

Received: September 29, 2006

Web Release Date: July 20, 2007 


\title{
Chemical Composition and Evaluation of Antibacterial and Antioxidant Activities of the Essential oil of Croton urucurana Baillon (Euphorbiaceae) Stem Bark
}

\author{
Euclésio Simionatto, ${ }^{*, a}$ Vanderléa F. L. Bonani, ${ }^{a}$ Ademir Farias Morel, ${ }^{c}$ Nilva Ré Poppi, ${ }^{b}$ \\ Jorge Luiz Raposo Júnior, ${ }^{b}$ Caroline Z. Stuker, ${ }^{c}$ Gisele M. Peruzzo, ${ }^{a}$ Marize T. L. P. Peres ${ }^{a}$ \\ and Sônia C. Hess ${ }^{a}$ \\ ${ }^{a}$ Departamento de Hidráulica e Transportes, Universidade Federal de Mato Grosso do Sul, \\ 79070-900 Campo Grande-MS, Brazil \\ ${ }^{b}$ Departamento de Química, Universidade Federal de Mato Grosso de Sul, \\ 79070-900 Campo Grande-MS, Brazil \\ ${ }^{c}$ Departamento de Química, Universidade Federal de Santa Maria, \\ 97105-900 Santa Maria-RS, Brazil
}

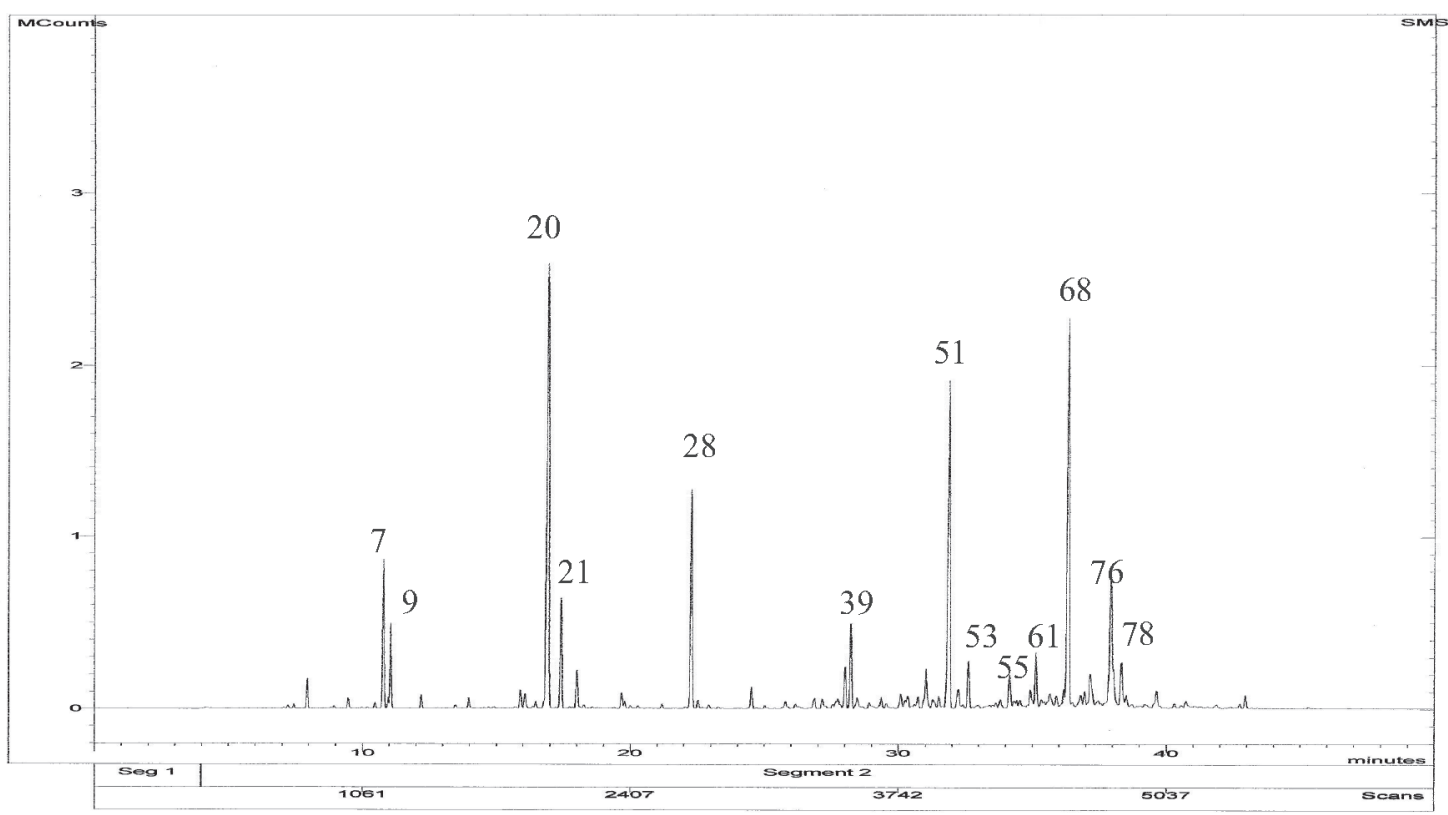

Figure S1. GC-MS chromatogram of the crude essential oil from stem bark of Croton urucurana. 


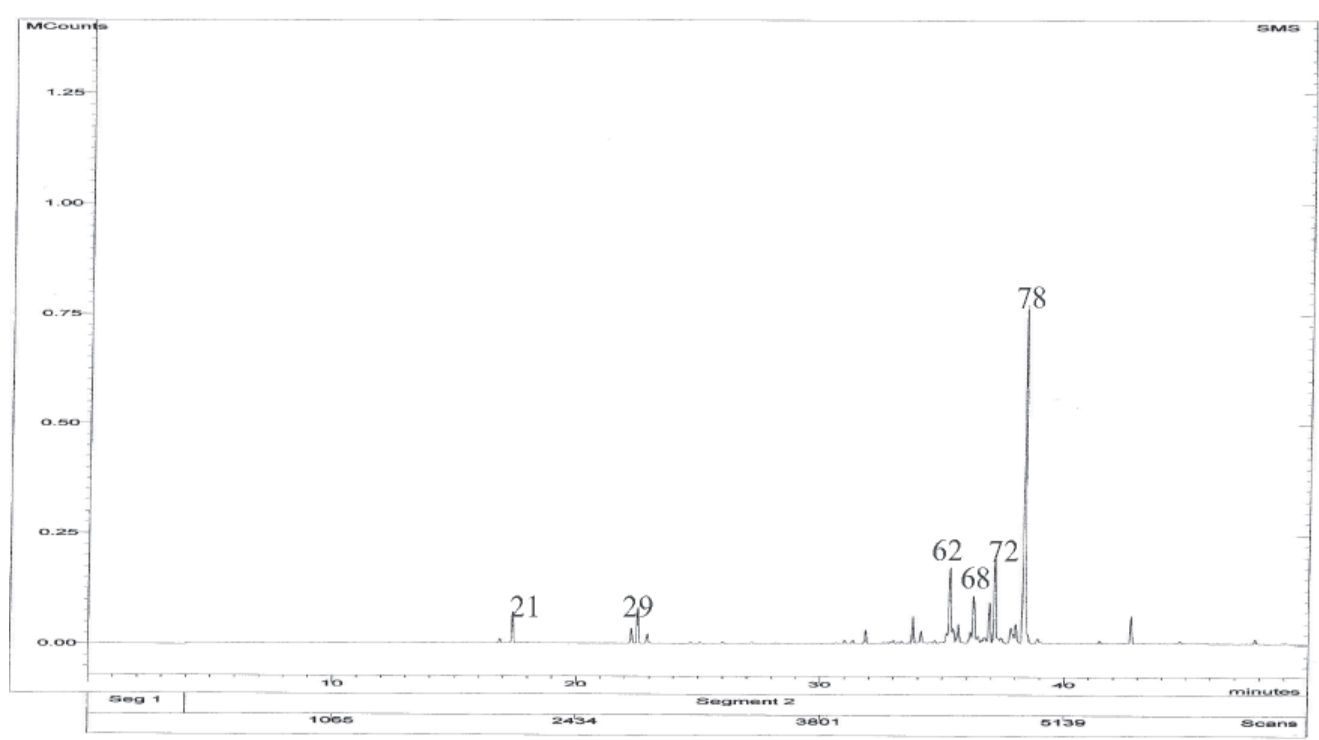

Figure S2. GC-MS chromatogram of the antioxidant fraction isolated from stem bark essential oil of Croton urucurana.

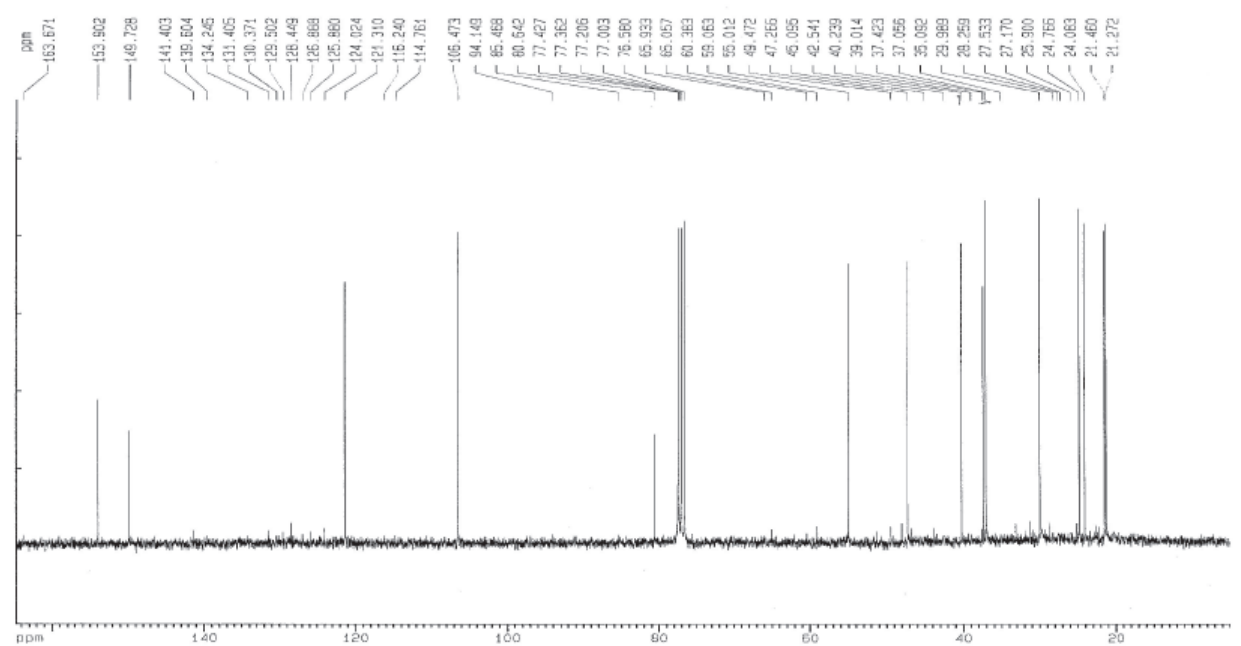

Figure S3. ${ }^{13} \mathrm{C}$ NMR spectra (in $\mathrm{CDCl}_{3}, 75 \mathrm{MHz}$ ) of the sesquiterpene (1) isolated from stem bark essential oil of Croton urucurana. 

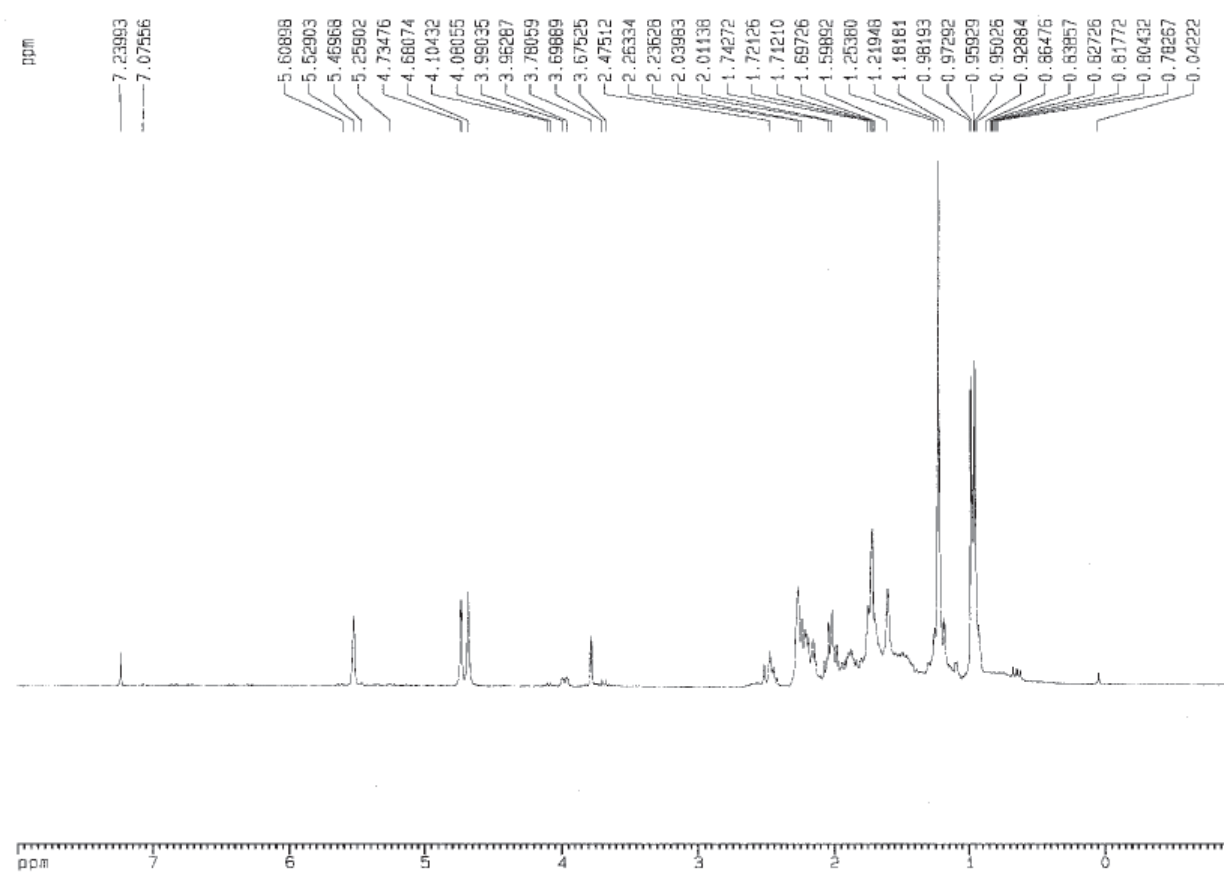

Figure S4. ${ }^{1} \mathrm{H}$ NMR spectra (in $\mathrm{CDCl}_{3}, 300 \mathrm{MHz}$ ) of the sesquiterpene (1) isolated from stem bark essential oil of Croton urucurana.

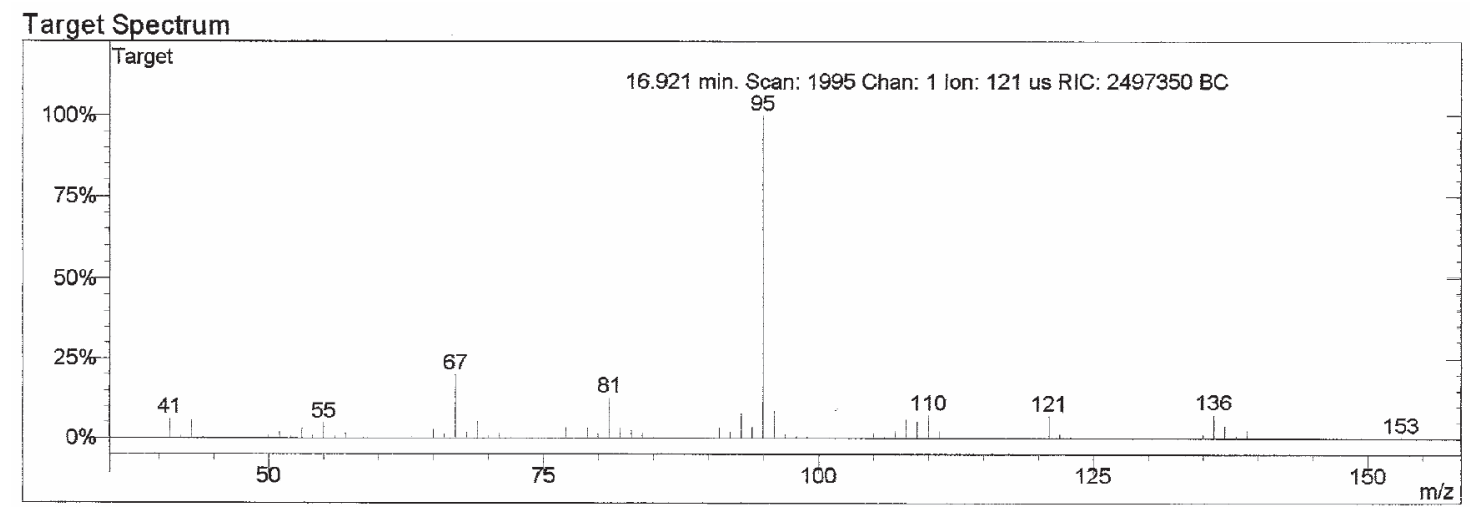

Figure S5. Mass Spectra of borneol.

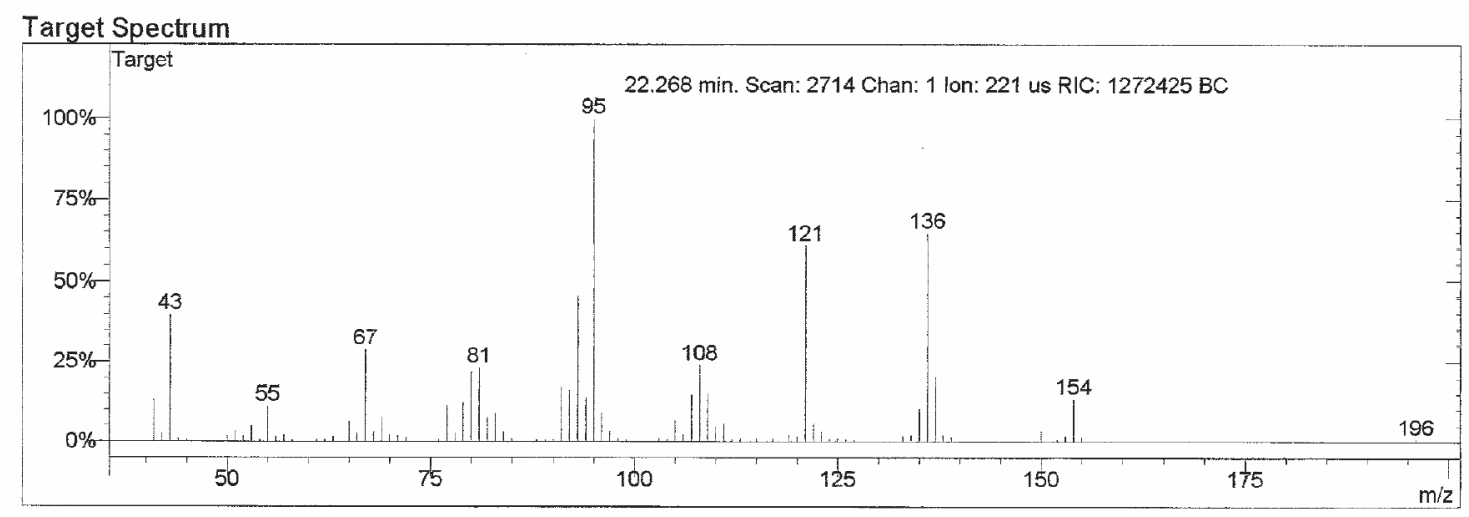

Figure S6. Mass Spectra of bornyl acetate. 


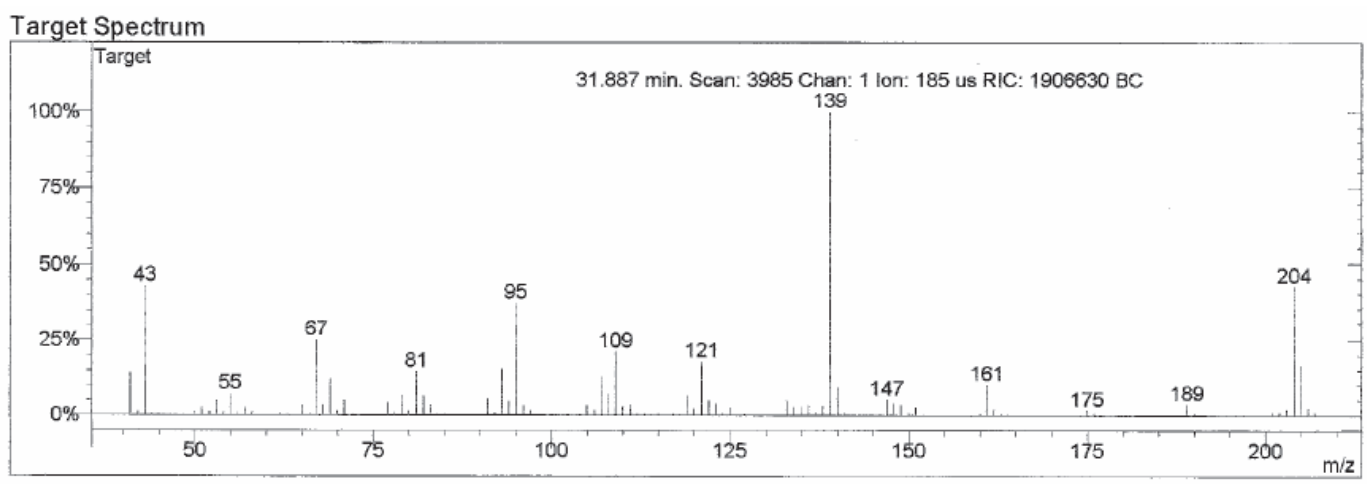

Figure S7. Mass spectra ot sesquicineole.

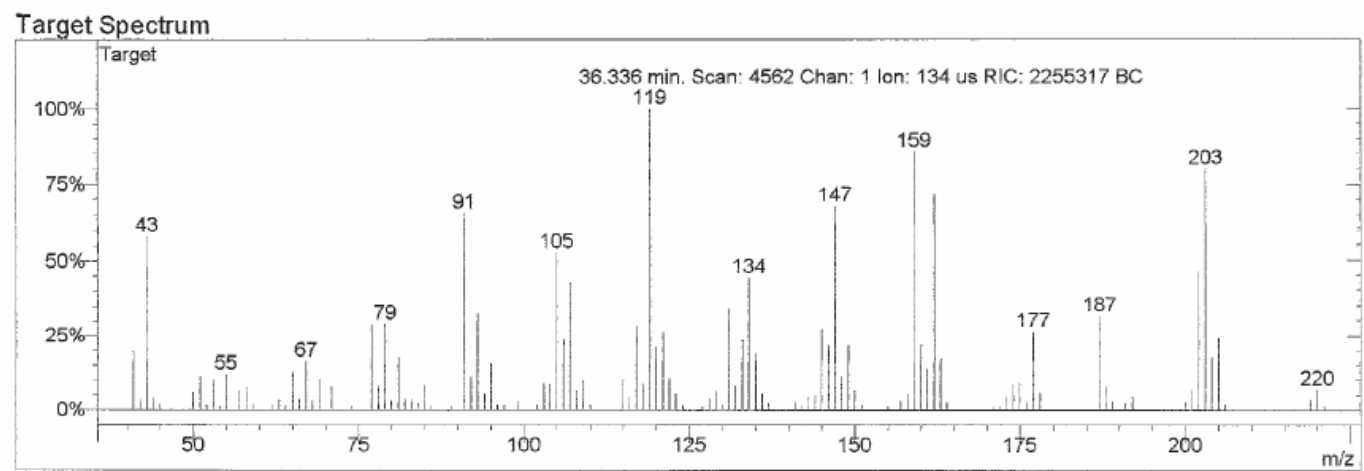

Figure S8. Mass Spectra of 1-isopropyl-7-methyl-4-methylene-1,3,4,5,6,8-hexahydro-2H-naphthalen-4-ol (1).

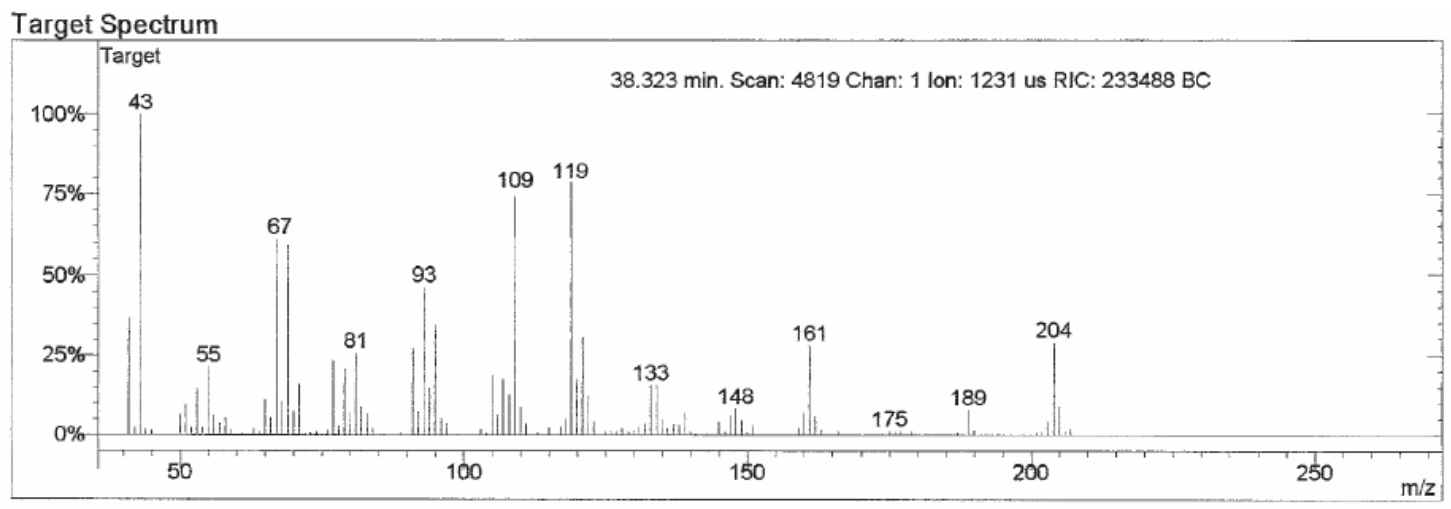

Figure S9. Mass Spectra of $\alpha$-bisabolol.

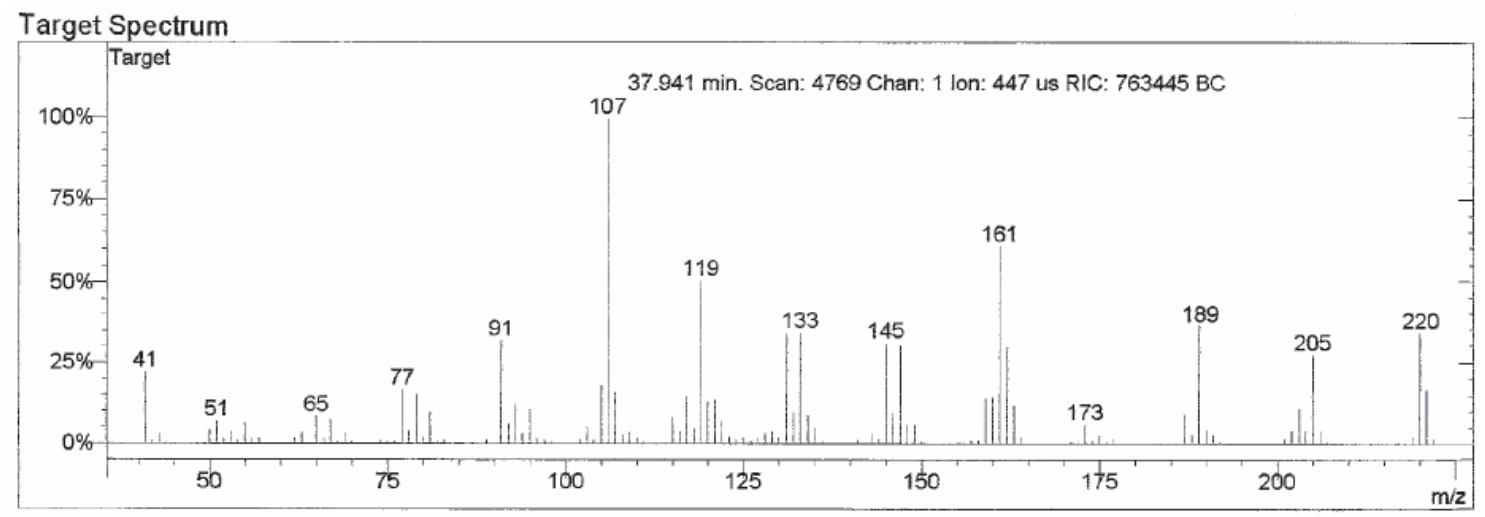

Figure S10. Mass Spectra of $\gamma$-gurjunene epoxide. 